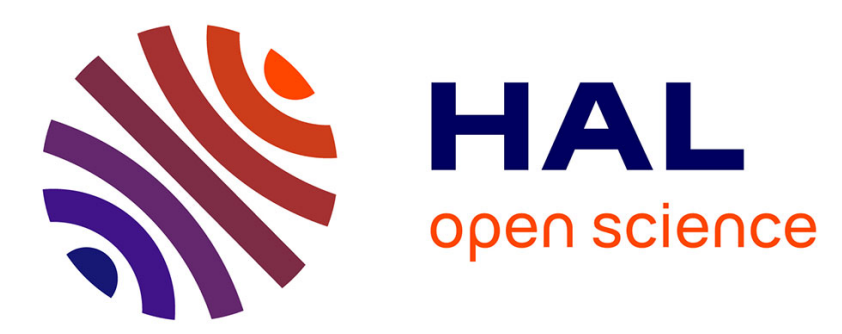

\title{
Comment about intestinal gluconeogenesis after gastric bypass in human in relation with the paper by Hayes et al., Obes. Surg. 2011.
}

\author{
Gilles Mithieux
}

\section{- To cite this version:}

Gilles Mithieux. Comment about intestinal gluconeogenesis after gastric bypass in human in relation with the paper by Hayes et al., Obes. Surg. 2011.. Obesity Surgery, 2012, 2012, epub ahead of print. 10.1007/s11695-012-0755-4 . inserm-00736540

\section{HAL Id: inserm-00736540 https://www.hal.inserm.fr/inserm-00736540}

Submitted on 28 Sep 2012

HAL is a multi-disciplinary open access archive for the deposit and dissemination of scientific research documents, whether they are published or not. The documents may come from teaching and research institutions in France or abroad, or from public or private research centers.
L'archive ouverte pluridisciplinaire HAL, est destinée au dépôt et à la diffusion de documents scientifiques de niveau recherche, publiés ou non, émanant des établissements d'enseignement et de recherche français ou étrangers, des laboratoires publics ou privés. 


\section{Letter to the Editor:}

\section{Comment about the paper by Hayes et al, Obes.Surg. 2011}

\section{Gilles Mithieux}

Inserm 855

Faculté Laennec

Rue Paradin,

69372 Lyon cedex 8

France

I wish to comment on the very interesting paper of Hayes and collaborators, who raised the question of the occurrence of intestinal gluconeogenesis after gastric bypass surgery in diabetic and non-diabetic obesity in human beings (Hayes et al, Is intestinal gluconeogenesis a key factor in the early changes in glucose homeostasis following gastric bypass? Obes. Surg. 2011, 21:759-762). Intestinal gluconeogenesis is a recently described function, which may influence both food intake and glucose homeostasis, when it is induced in rats or mice (for review: Mithieux et al, 2009). The induction of intestinal gluconeogenesis translates into a release of glucose in the portal vein, where glucose sensors exist and may transmit a signal to the brain. This curbs hunger and improves insulin sensitivity of hepatic glucose production. This essentially takes place in two situations in rats and mice: 1) after feeding a protein-enriched diet (Duraffourd et al, 2012; Mithieux et al, 2005; Pillot et al, 2009); 2) after gastric bypass surgery (Troy et al, 2008). 
In their paper, Hayes et al question whether intestinal gluconeogenesis may take place in obese diabetic and non-diabetic patients after a gastric bypass. Six days after the operation, they studied plasma glucose concentration in central and portal blood, with the assumption that an increase in plasma glucose should highlight intestinal gluconeogenesis, if the latter is significant. The blood samplings were done in $8 \mathrm{~h}$-fasting state. This is a time sufficient to reasonably exclude that glucose from the last meal could appear in the portal blood (Hayes et al, 2011). They found no difference in glucose concentrations in portal versus central blood in obese diabetic and a small, but significant, glucose increase in portal blood in obese non-diabetic subjects (table 1). They concluded that this provides no evidence that intestinal gluconeogenesis may contribute to the resolution of type 2 diabetes seen after gastric bypass. On the other hand, the net glucose release $(+0.2 \mathrm{mmol} / \mathrm{L})$ suggested the occurrence of intestinal gluconeogenesis in the obese non-diabetic subjects. Nevertheless, the authors concluded that it seems unlikely that such a small increase in portal glucose concentration would be sufficient to trigger the portal sensor.

I would like to point out that, in my opinion, two important issues have been overlooked in this rationale. The first is that the gut is a strong glucoseutilizing organ, because of its high glycolytic activity. This is true in rodents as in human. Hence, it is considered that the gut may account for $15-20 \%$ of the total glucose utilization of the body in the post-absorptive situation (for review: Mithieux, 2001). As a consequence of this high glucose uptake by the intestine, there is a decrease in portal glucose concentration in all the situations where intestinal gluconeogenesis is not detectable (table 2). Moreover, when intestinal gluconeogenesis is triggered in rats or mice, it is just sufficient to counterbalance intestinal glucose uptake, so that the decrease in portal glucose concentration does not longer take place (table 2). We have previously demonstrated that such an absence of glucose decrease in the portal vein is 
sufficient to recruit the portal glucose sensors and promote hunger-curbing effects (Duraffourd et al, 2012; Mithieux et al, 2005; Troy et al, 2008). This means that intestinal gluconeogenesis could take place in the obese patients studied by Hayes et al, at a level equivalent to intestinal glucose utilization in diabetics (perhaps $15-20 \%$ of endogenous glucose production (EGP), see above), or even at a level significantly higher than glucose uptake in the nondiabetics.

The second point relates to the blood flood irrigating the intestine, which is relatively high. In humans, the blood flow through the intestine in the postabsorptive situation is estimated to rate to about $14 \mathrm{~mL} / \mathrm{kg} / \mathrm{min}$, which represents, e.g., about $1 \mathrm{~L} / \mathrm{min}$ for a normal individual weighing $70 \mathrm{~kg}$ or 2 $\mathrm{L} / \mathrm{min}$. for a obese people weighing $140 \mathrm{~kg}$. It is, therefore, easy to calculate that an increase of $0.2 \mathrm{mmol} / \mathrm{L}$ in the blood exiting the gut (i.e. what is expected to take place in the portal blood in the obese non-diabetic subjects studied by Hayes et al) may represent a actual flux of $0.2(\mu \mathrm{mol} / \mathrm{ml}) \times 14(\mathrm{~mL} / \mathrm{kg} / \mathrm{min})=2.8$ $\mu \mathrm{mol} / \mathrm{kg} / \mathrm{min}$. EGP in human in the post-absorptive state is assumed to rate to about $2 \mathrm{mg} / \mathrm{kg} / \mathrm{min}$, i.e. $11 \mu \mathrm{mol} / \mathrm{kg} / \mathrm{min}$. One may thus infer that this net increase in glucose concentration $(+0.2 \mathrm{mmol} / \mathrm{L})$ in the portal blood might actually represent about $25 \%(2.8 / 11)$ of total EGP in obese subjects after gastric bypass surgery. Although this may appear high, it should be emphasized that "true" intestinal gluconeogenesis must yet be higher. Indeed, one has to add to this number the intestinal glucose production rate, which has also enabled to counterbalance intestinal glucose utilization. It must, however, be stressed that one has to be cautious on these estimations on a quantitative viewpoint, since both EGP and/or intestinal blood flow may be slightly different in normal subjects and obese patients.

The last point deserving to be discussed relates to the equality in glucose concentrations in portal and central bloods during the time of surgery in both 
diabetic and non-diabetic patients (see table 1). According to the rationale above, this suggests that intestinal gluconeogenesis could take place at a rate enabling to counterbalance glucose uptake. One may also reasonably exclude that glucose could derive from food during the time of surgery. It is noteworthy to remind here that this is very comparable to what was observed by Battezzati et al (2004), who raised the question of renal and intestinal glucose productions during the an-hepatic phase of liver transplantation in human. From both arteriovenous glucose balance and glucose tracer studies, they could estimate that the absence of glucose production by the liver was compensated by glucose release from the kidney (for $70 \%$ ) and the intestine (for the rest, i.e. about 30\%). They emphasized that this was likely dependent on the dramatic increase in stress hormones taking place during the operation, which did no longer exist some time afterwards (Battezzati et al, 2004). Whereas stress hormone concentrations were not reported in Hayes et al, 2011, it may be expected that they should be increased during the time of gastric bypass surgery, explaining why intestinal gluconeogenesis could be sufficient to hinder portal glucose concentration to be diminished.

I would like to conclude that, examining the data of Hayes et al (table 1) and those in rodents (table 2), intestinal gluconeogenesis could be significant in both diabetic and non-diabetic obese patients 6 days after gastric bypass surgery. Moreover, on a quantitative point of view, it could be equivalent to that estimated in rodents, at least in obese non-diabetics.

\section{Conflicts of interest statement:}

The author declares he has no conflict of interest in relation to this paper.

References:

Battezzati A, Caumo A, Martino F, Sereni, LP, Coppa J, Romito R, Ammatuna M, Regalia E, Matthews DE, Mazzaferro V and Luzi L. Nonhepatic glucose 
production in humans. Am. J. Physiol. Endocrinol. Metab., 2004, 286:E124E135.

Duraffourd C, De Vadder F, Goncalves D, Delaere F, Penhoat A, Brusset B, Rajas F, Chassard D, Duchampt A, Stefanutti A, Gautier-Stein A and Mithieux G. $\mathrm{M} \mu$-opioid receptors and dietary protein stimulate a gut-brain neural circuitry limiting food intake. Cell, 2012, sous presse.

Hayes MT, Foo J, Besic V, Tychinskaya $\mathrm{Y}$ and Stubbs RS. Is intestinal gluconeogenesis a key factor in the early changes in glucose homeostasis following gastric bypass ? Obesity and Surgery, 2011, 21:759-762.

Mithieux G. New data and concepts on glutamine and glucose metabolism in the gut. Curr. Opin. Clin. Nutr. Metab. Care, 2001, 4:267-271.

Mithieux G, Andreelli F, Magnan C. Intestinal gluconeogenesis: key signal of central control of energy and glucose homeostasis. Curr. Opin. Clin. Nutr. Metab. Care, 2009, 12:419-423. Review

Mithieux G, Misery P, Magnan C, Pillot B, Gautier-Stein A, Bernard C, Rajas F, Zitoun C. Portal sensing of intestinal gluconeogenesis is a mechanistic link in the diminution of food intake induced by diet protein. Cell Metab., 2005, 2:321-329.

Pillot B, Soty M, Gautier-Stein A, Zitoun C and Mithieux G. Protein feeding promotes redistribution of endogenous glucose production to the kidney and potentiates its suppression by insulin. Endocrinology, 2009, 150:616-624.

Troy S, Soty M, Ribeiro L, Laval L, Migrenne S, Fioramonti X, Pillot B, Fauveau V, Aubert R, Viollet B, Foretz M, Leclerc J, Duchampt A, Zitoun C, Thorens B, Magnan C, Mithieux G and Andreelli, F. Intestinal gluconeogenesis is a key factor for early metabolic changes after gastric bypass by not after gastric lap-band in mice. Cell Metabolism, 2008, 8:201-211. 
